\title{
O Regime Modernizante Brasileiro
}

\author{
J. O. de Meira Penna \\ Embaixador, diplomata de carreira, psicólogo, \\ escritor e professor universitário
}

Temos ouvido recentemente queixas, até certo ponto justificadas, de que só autores estrangeiros - os americanos com primazia - estariam estudando objetiva e seriamente os acontecimentos relacionados com a Revolução e o Desenvolvimento de nosso país. É fato que tem havido poucos pesquisadores brasileiros desse tipo: pesquisas que cubram sobriamente todo o panorama da realidade política, social e econômica do Brasil. Talvez falte aos estrangeiros que nos observam e nos criticam, uma compreensão mais aguda das origens de nossa Revolução, bem como das perspectivas que se abrem para o país como resultado do fenômeno de rapidíssima expansão industrial em andamento. Em compensação, menos envolvidos emocionalmente nesses acontecimentos, os cientistas estrangeiros se valem de uma visão quiçá mais fria, menos comprometida por preconceitos ideológicos. $\mathrm{O}$ que não quer dizer que sejam isentos na avaliação dos méritos e, porventura, dos defeitos do "sistema" que nos governa há quase dez anos.

Entre esses estudiosos da realidade brasileira ponho de lado, inicialmente, jornalistas superficiais como o francês François de Combret que, no Brasil, só vêem uma "grande tragédia" miséria, despotismo e torturas, como se fôssemos o Haiti de Papa Doc. Basta saber que seus principais informadores são os Arcebispos de Recife e Crateus para se ter uma idéia do tom do livro. O que ele lamenta é que o Brasil não seja governado por homens como Fidel Castro ou Salvador Allende (o livro foi escrito em 1971!). Partindo do princípio de que a miséria de certas nações ou do Nordeste Brasileiro é fruto do imperialismo econômico americano, não poderia deixar de chegar a conclusões 
ineptas após sua viagem turística por nossa terra. Com esses pseudo-intelectuais do Quartier Latin não há debate.

Prefiro gente mais séria. Ocorrem-me os nomes de quatro cujas obras se destacam particularmente por sua atualidade e pelo largo espectro de seu interesse, além de mais alguns que serão mencionados no decorrer de nosso ensaio. São os professores Thomas Skidmore, Ronald Schneider e Alfred Stepan, americanos, e o suíço G. E. Fiechter. Examinam todos a conjuntura brasileira do ponto de vista do regime dominante e dos resultados obtidos no que diz respeito à aceleração do desenvolvimento econômico e às transformações estruturais na nossa carcomida organização política. Se as interpretações e previsões desses pesquisadores, mesmo numa perspectiva de poucos anos, se revelam às vezes claramente errôneas, possuem, pelo menos, o mérito de chamar a atenção para aspectos que provavelmente nos passariam despercebidos.

Os melhores estudiosos americanos reconhecem, de um modo geral, que a "crise brasileira" é o resultado de uma problemática institucional muito complexa. O fato é que fomos incapazes de criar, até agora, órgãos e processos políticos democráticos capazes de corrigir, dirigir ou encaminhar as mudanças econômicas e sociais muito profundas que estão transformando o país desde 1930. Haveria assim um desequilíbrio crescente entre as instituições existentes e a sociedade em benefício da qual deveriam supostamente operar. Thomas Skidmore pergunta muito à propos, "como reconciliar os ideais democráticos e as tensões sociais resultantes do fosso entre as mudanças econômicas aceleradas do passado recente e a tarefa enorme de desenvolvimento a ser empreendida?". Ronald Schneider proclama: "O Brasil é um gigante adolescente em séria aflição (trouble)". Um fator importante da instabilidade brasileira seria o gap, a brecha crescente entre o ritmo das transformações e a mobilização adequada de novos grupos ou elites dirigentes civis.

Um outro professor americano, de alto gabarito, Samuel Huntington, que tem estudado o problema em todos os países do chamado "Terceiro Mundo", enfatiza igualmente o lag ou atraso no desenvolvimento de instituições políticas, em relação à rapidez das mudanças sociais e econômicas, no período de pósguerra, na Ásia, Africa e América Latina. Teria ali ocorrido um declínio geral na ordem política, com subversão da autoridade e redução da legitimidade e eficiência dos governos. Numa fór- 
mula de impacto, declara Huntington que "a modernidade gera estabilidade, mas a modernização gera a instabilidade"...

Já a idéia de que não poderia haver desenvolvimento acelerado sem certa dose de constrangimento ou imposição parece acentuar-se entre alguns observadores. $O$ debate restringir-se-ia, nesse caso, à questão da natureza e extensão do poder de constrangimento, bem como ao modo de seleção das pessoas que o exercem. G. A. Fiechter, o mais simpático de todos esses analistas de nossa situação, acredita que "a planificação autoritária é provavelmente necessária, pois é preciso impor ao mesmo tempo sacrifícios a curto prazo, a redistribuição dos recursos existentes e a revisão dos métodos pelos quais são tais recursos distribuídos".

Essa problemática levanta a questão da interpretação marxista da realidade brasileira. Parece inacreditável, mas é infelizmente verdadeiro, como preconceitos marxistas ou cripto-marxistas contaminam as apreciações de muitos desses "sábios", inclusive catedráticos da livre América, desses acadêmicos da pátria do capitalismo triunfante. É inegavel que a má vontade com que, às vezes, indisfarçadamente observam os acontecimentos de nosso país não é apenas o produto natural de uma perspectiva liberal. Se assim fosse, mais severos seriam, por exemplo, com a experiência do Peru onde os militares, fardados e de espada, são realmente os "ocupantes" do país. Severos ainda mais seriam com Cuba a qual, no entanto, parece merecer-lhes um enternecido e tolerante silêncio. Quando Fidel encosta um adversário no paredon, tal ato é classificado como o devido castigo de um burguês opressor e reacionário, vermina desprezível que deve ser eliminada. Quando Pinochet faz o mesmo com os marxistas, é tratado de brutal ditador, fascista, capacho dos americanos e lacaio do imperialismo.

Indubitavelmente, os sóbrios catedráticos da Columbia University não conseguem, às vezes, pesquisar temas tão altamente carregados de conteúdo emocional, sem se render também às sugestões maliciosas do íncubo ideológico que os possui. $O$ Professor Bradford Burns, por exemplo, um historiador especializado no Brasil, exalta o nacionalismo brasileiro que interpreta exclusivamente em termos de antiamericanismo. Com esse tipo peculiar de masoquismo e auto-flagelação, tão do gosto dos intelectuais de nossa época, ele só acredita na sinceridade democrática antiimperialismo do político ou do autor que saiba vociferar suas denúncias ao imperialismo yankee. Lembro-me que, cri- 
ticando em 1967 meu livro "Política Externa - Segurança e Desenvolvimento", o Prof. Burns achou-o pouco nacionalista. Ao descrever as tendências "tradicionalistas" que dominavam a diplomacia brasileira sob a Presidência Castello Branco, considerou, como enorme e imerecido exagero, que esse regime "estava implementando a política tão habilmente defendida pelo Embaixador Meira Penna. Para ele, nacionalistas só seriam Goulart, Brizola, os abencerragens do antigo ISEB ou, em outras palavras, só aqueles que agridem Washington para agradar Moscou.

O problema é que o "modelo brasileiro" de desenvolvimento está tendo sucesso, ao passo que o modelo marxista, posto em prática em Cuba, no Chile e alhures só conduz ao fracasso. Fidel Castro, por exemplo, em que pese o milhão de dólares que recebe diariamente da União Soviética, só conseguiu mesmo foi perder para o Brasil o primeiro lugar na exportação de açúcar, confirmando assim o comentário amargo de Anastás Mikoyan, segundo o qual Socialismo e Rumba não se combinam bem...

Não podemos, contudo, generalizar a crítica a essa atitude paradoxal que reflete a gravidade da crise moral por que atravessa a Universidade americana. Outros observadores, menos contaminados pela pestilência, reconhecem que os acontecimentos brasileiros não se submetem tão facilmente à cama de Procusto da dogmática marxista. Ruy Mauro Marini é um que confessa que não se pode interpretar a realidade brasileira segundo "a lógica impecável da luta de classes". Ainda bem! Outros reconhecem que a Revolução brasileira não tornou nosso país mais subserviente, política e economicamente, aos Estados Unidos, porém menos. Aliás Celso Furtado também admite que o operário de S. Paulo, vindo das áreas pobres de emigração interna, do Nordeste, "se sente desde o princípio integrado num processo de elevação de estatuto social".

A análise dos acontecímentos brasileiros, entre 1930 e 1964, não é tampouco muito fácil para quem se orienta exclusivamente segundo critérios tirados da experiência democrática americana. John W. F. Dulles, filho do antigo Secretário de Estado e professor de estudos Latino-Americanos na Universidade do Texas, aceitou o desafio, escrevendo dois eruditos livros sobre o período. Neles se limita a relatar os fatos, reduzindo ao mínimo os comentários pessoais. O resultado é um pouco seco, mas a objetividade me parece garantida. A Esquerda Festiva 
brasileira, entretanto, bufou! O mínimo de que foi acusado é de ser filho de John Foster Dulles... o que prova como é difícil satisfazer os dois campos, mantendo-se no centro.

Thomas Skidmore aproxima-se também da verdade sem nunca, porém, tocá-la de chofre. Devemos perdoá-lo, pois os historiadores e sociólogos brasileiros também nunca estudaram muito profundamente os acontecimentos de 30 a 64, especialmente nunca se atreveram a pesquisar exaustivamente o fenômeno do Getulismo. Limitaram-se a analisar literariamente a personalidade fascinante desse que foi o único ditador e o maior líder carismático de nossa história - ora a favor, ora contra, raramente com isenção. Certos temas, contudo, mereceriam enfoque especial: a expansão monstruosa do eleitorado, grande parte do qual passando a escapar do voto de cabresto; o reforço permanente do governo central no contexto da federação; a extrema capacidade de sobrevivência da velha classe de políticos, através de todas as perturbações constitucionais e da anarquia partidária; a inexperiência, a incompetência e a divisão das Esquerdas e, finalmente, a fraqueza e perplexidade do grupo que Skidmore denomina "liberais constitucionalistas".

A opção fundamental do Brasil entre a queda de Getúlio, em 1945, e o golpe de 31 de março de 1964 ter-se-ia colocado, segundo Skidmore, entre os liberais constitucionalistas que corresponderiam, grosso modo, aos membros sinceros da UDN, com seus aliados do PL e do PR, e os semi-autoritários nacionalistas cuja principal preocupação teria sido a "regeneração nacional" e a modernização do país.

Esse esquema possui valor e alguns defeitos. Seu mérito é escapar da classificação ideológica vulgar que esquizofrênicamente polariza a Esquerda e a Direita. É uma construção que, entretanto, colocariam a antiga UDN em oposição ao regime atual. Não me parece que seja uma fórmula de explicação satisfatória para as ocorrências do momento, uma vez que encontramos udenistas do lado de cá da cerca, e semi-autoritários nacionalistas do lado de lá.

O ponto de vista de Skidmore bem descreve, no meu entender, as perplexidades enfrentadas pelos liberais constitucionalistas desde quando se frustraram os ideais da Revolução de 1930 , a qual foi concebida, como vale recordar, pela chamada Aliança Liberal. A primeira decepção data de 1933 em São Paulo. A incompreensão dos intelectuais e políticos liberais sinceros 
está patente no voto do Primeiro Congresso de Escritores, em 1945 , que pediu um governo eleito pelo "voto universal, direto e secreto". Será que imaginavam as conseqüências imediatas e futuras de um tal programa? A Constituição de 46 incorporou seus desejos, combinados com os dos nacionalistas, favoráveis a um governo mais forte. Uma contradição que nunca foi resolvida.

As eleições que se sucederam só raramente deram o poder a estadistas liberais competentes os quais, desde o princípio, tiveram a amarga surpresa de verificar que o eleitorado consistentemente preferia os demagogos e líderes carismáticos - o que quer dizer, o ex-ditador, seus maus herdeiros-e seus péssimos imitadores - a qualquer figura de democrata, por mais respeitável que fosse. Rodrigues Alves Filho refletiria a tristeza e a perplexidade da UDN ao acentuar que o voto não resolvia porque ao povo não eram dados os meios de escolher livremente indivíduos decentes (mas, perguntamos nós, que meios são esses?).

O derradeiro recurso desses liberais foi deixar-se atrelar à carruagem demagógica do candidato Jânio Quadros, isso, não obstante o fato de Jânio aparecer como o antipolítico por excelência, o inimigo dos partidos de velho estilo. A "Vassoura" ia tudo carregar e certamente tudo teria carregado, inclusive a própria UDN e seu sonho constitucionalista, não fosse a surpresa de agosto de 1961. Skidmore observa, com razão, que o desastre da democracia liberal brasileira ocorreu nas eleições de 1960 e não tanto pela eleição de Jânio Quadros, quanto pela derrota de Milton Campos. O eleitorado elegeu o primeiro. E deixando de preferir Mílton Campos, permitiu a Jânio Quadros o jogo dúbio da renúncia. Skidmore aponta para a esquizofrenia da chapa Jan-Jan: um Presidente independente e da oposição (que devia varrer toda a herança do Getulismo) e um Vice-Presidente que representava as forças situacionistas getulistas. Na realidade, a eleição provou que o fator dominante era personalista e não ideológico-programático.

Mas, anteriormente, o povo já preferira Eurico Dutra ao herói de 1922, Eduardo Gomes, levando em consideração não as virtudes daquele austero militar que nos deu um dos mais pacíficos e estáveis goverenos da República, mas o fato de ser apoiado por Getúlio. Eduardo Gomes e Juarez Távora foram, posteriormente, derrotados de novo. A volta de Getúlio ao poder não teria sido suficiente para solapar a confiança dos liberais democrá- 
ticos nos processos eleitorais. Um meio termo teria sido realizado com a eleição de Juscelino Kubitschek - mas como custou! Skidmore analisa o governo JK como atingindo aos limites da política de improvisação: os problemas econômicos e sociais se iam acumulando ameaçadoramente (sobretudo sob a forma de suas conseqüências financeiras, a inflação), enquanto as instituições representativas se revelavam cada vez menos adequadas, quando sujeitas a um eleitorado ignorante e caprichoso.

Comenta o professor, longamente, as "relações angustiantes" entre os liberais-constitucionalistas e os militares, desde 1954. Era evidente que a UDN procurava compensar, através do apelo à intervenção militar, sua incapacidade de seduzir o eleitorado no sentido de uma escolha mais perfeita.

A especulação que surge então, amiúde, tanto em autores brasileiros quanto nos estrangeiros, diz respeito à fraqueza da organização partidária brasileira, à qual é atribuída o próprio colapso institucional finalmente ocorrido. Que o tema haja sido alvo de graves preocupações oficiais, a prova está no empenho dos próprios revolucionários em reformar e fortificar, pelo $\mathrm{Al}-2$, seguido de outras medidas complementares, a estrutura dos partidos. Entre os estudiosos nacionais que hão martelado nesse tema vale mencionar o Prof. Orlando Carvalho, que chefia um de nossos melhores grupos de pesquisadores políticos na UFMG.

Skidmore observa que o estado clientelista, de estilo pré1930, não se modificou na mentalidade de muitos parlamentares. Continuavam vendo seu papel como consistindo exclusivamente em dividir o espólio e conquistar favores para seus associados. Nota ainda que a falta de definição das linhas partidárias é exemplificada pelo fato de que, em 1962, só 216 dos 409 deputados haverem sido eleitos nas respertivas legendas. As alianças de partidos, as mais complexas e escandalosas, jogavam os programas às urtigas. Para Skidmore, 'ada partido tornou-se um microcosmo do espectro político nacional, passavelmente anárquico.

Tanto esse autor quanto Ronald Schneider estão seguindo, nesse terreno, a liderança intelectual do Prof. Huntington. Huntington é o grande guru da ciência política no que se refere aos países do Terceiro Mundo e é de Huntington a fórmula: "a susceptibilidade de um sistema político modernizante à intervenção militar varia inversamente à força dos partidos políticos". 
Um sistema partidário tradicional e bem montado seria pré-condição de estabilidade política democrática.

Não se pode criticar essa tese, ela tem muito que lhe faz merecer integral apoio. Lembro-me que, em 1965, ao coordenar um grupo-tarefa de estagiários da ESG, engajados no ciclo final de planejamento do Curso Superior de Guerra, me empenhei com fervor nas discussões então travadas sobre nossa caótica organização partidária. Chegamos então ao consenso de que o bipartidarismo muito poderia contribuir para o fortalecimento das instituições democráticas, tendo como modelo os Estados Unidos e a Grã-Bretanha. Fácil é adivinhar nossa surpresa quando, logo em seguida, foi oficialmente adotada a idéia que havíamos especulativamente debatido: foram criados o MDB e a ARENA.

O momento não é próprio para nos empenhar aqui num aprofundamento dessa questão. Desejo apenas lembrar alguns acontecimentos históricos, remotos e recentes, que enfraquecem grandemente nosso enternecido apoio ao partidarismo tradicional. Cito em primeiro lugar o caso da Alemanha, na década dos 30 , a qual, possuindo um velho partido social-democrático, sólidos partidos conservadores e um PC fortemente entrincheirado (e mesmo armado) na classe proletária, foi levada de roldão pelo NSDAP hitlerista.

A França apresenta igualmente um robusto quadro partidário na Terceira República: mas que resistência ofereceu, na hora amarga da crise colonial e diante do putsch dos generais de Alger? De Gaulle fundou o Rassemblement du Peuple Français cujo nome parece destinado a indicar que transcende todos os partidos. Em muitos outros lugares, o "partido" passou a ser uma palavra feia... Nos países totalitários o Partido único alcançou mesmo esse prodígio lógico de se pretender "parte" e constituir o "todo".

Mais perto de nós vemos, na Argentina, os velhos partidos Radical e Conservador serem carregados pela maré incontrolável do Justicialismo peronista. E o caso do Chile? Durante três anos ouvimos repetir, ad nauseam, que uma intervenção militar seria impensável, para derrubar o catastrófico Allende, porque os partidos tradicionais, fortemente estruturados, não o permitiriam. 
A meu ver, o exemplo mais clamoroso é o da Colômbia. Desde 1830, o que quer dizer, há mais tempo do que nos Estados Unidos, conhece aquele nosso vizinho e amigo dois fortes partidos, um liberal e outro conservador. São bem estruturados ideologicamente, possuem velha tradição e representam, não classes, mas setores verticais da opinião pública nacional. No entanto, poucos países sofreram disputas sectárias tão longas e tão ferozes quanto a Colômbia (Leia-se o romance de Garcia Marquez "Cem Anos de Solidão"...). Em fins do século passado, uma guerra civil entre liberais e conservadores teria enterrado mais de uma centena de milhares de mortos. La Violência de quase duas décadas, que se seguiu ao famoso Bogotazo de abril de 1948 , teria sacrificado perto de trezentas mil almas, degenerando em verdadeiro banditismo, provocando a intervenção brutal de um caudilho militar e acarretando, finalmente, como derradeiro recurso para deter a sangria, um acordo bipartidário, a Frente Nacional, que é a própria negação do sistema, pois estabelece a alternância automática da Presidência entre conservadores e liberais. O exemplo colombiano constitui, infelizmente, um desmentido às virtudes absolutas do bipartidarismo que, levado a tais extremos, se transforma numa verdadeira psicose coletiva.

Mas é, a meu ver, em torno do problema central da liderança carismática ou populista que os pesquisadores estrangeiros, aqui examinados, me parecem conduzir seus barcos de encontro aos escolhos. Poucos compreenderam o papel do personalismo exacerbado de nossa vivência política e nenhum, talvez, se convenceu de que a verdadeira opção brasileira - como aliás a de nossos vizinhos sul-americanos - não é a alternativa vulgar entre militarismo autoritário nacionalista, de um lado, e plenitude democrática, do outro, mas sim entre um regime racionallegal que faz respeitar a lei e traz estabilidade, e um sistema baseado no prestígio entusiástico mas transitório, instável e despótico do líder carismático, com intermezzos anárquicos.

Ronald Schneider fala superficialmente nas "panelinhas", no coronelismo e no sistema feudal de governo. Nem ele nem Huntington, porém, dão valor ao populismo e o relacionam com o velho personalismo da tradição feudal-colonial. Schneider oferece, sem maiores discussões, uma classificação de quatro tipos de populismo que seriam:

a) o nacionalista, orientado para o trabalhismo (Getúlio Vargas); 
b) o conservador-demagógico, clientelista (Ademar de Barros);

c) o moralizador messiânico (Jânio Quadros); e

d) o zeloso na cruzada anticomunista (Carlos Lacerda).

Nessa classificação, João Goulart seria um "Vargas de segunda classe" e um "ersatz Peron". A classificação é útil até certo ponto, mas imperfeita. O trabalhismo de Getúlio Vargas, por exemplo, só se manifestou na segunda fase de seu domínio político (após a fase pseudo-fascista de 1935-1940). E o impacto de Carlos Lacerda não se limitou à cruzada anticomunista, antes competindo com Jânio Quadros no apelo moralizador messiânico.

Skidmore salienta melhor esse aspecto de nossa vida política. Ele reconhece, de início, que o Estado Novo foi uma "criação altamente pessoal". O líder populista seria um político de novo estilo, produzido numa situação em que um eleitorado urbano maciço demonstra receptividade a um tribuno "colorido" que recorre à atração emocional direta, ao focalizar problemas econômicos imediatos das massas, de sofisticação ideológica
variável.

Tal tipo de liderança, acentua, era impensável antes de 1930. A organização política personalística que o demagogo cria ex nihilo, visa satisfazer-lhe a própria ambição e carreira. Ele é temido pela direita e desprezado pelos marxistas ortodoxos porque "mistificam" as massas. "Nos últimos vinte anos, afirma Skidmore, os políticos populistas demonstraram ser formidáveis caçadores de votos no Brasil".

A falha desse raciocínio reside, segundo creio, em desconhecer que o líder populista é uma figura "moderna", evoluída, do perene anseio sebastianista do povo brasileiro; representando, por outro lado, uma simples transposição para o ambiente das grandes cidades litorâneas, tendo como instrumento o voto, do laço afetivo interpessoal que sempre uniu o "homem do povo" ou o caboclo a seu Pai-Padrinho-Patrão sertanejo.

O francês Morazê, em "Les Trois Ages du Brésil", já comparava o coronelismo e o populismo. Esse professor reconhece a diferença entre o primeiro, que é feudal, rural e tradicional, e o segundo que é urbano e imprevisível. Mas não desconhece que a semelhança entre os dois fenômenos se fundamenta no mesmo tipo de laço emocional personalista. O próprio Getúlio Vargas, R. Serv. públ., Brasília, 108 (3) set./dez. 1973 
por exemplo, revelou o ponto de contacto entre o coronelismo e populismo ao fundar, simultaneamente, o PSD que representava o primeiro, e o PTB que exprimia o segundo. Para cada um desses partidos, usou um estilo próprio, mas sempre encarnado o Pai-Padrinho-Patrão que "vai salvar o Brasil"...

Na realidade, os três tipos de apelo sebastianista, o moralizante reformista de Jânio Quadros e Carlos Lacerda, o desenvolvimentista, de natureza entusiástica extrovertida de Ademar de Barros e Juscelino Kubitschek, e o de reforma social imediata (João Goulart e Getúlio Vargas), reforçam-se com o apelo nacionalista e a procura de bodes-expiatórios no exterior. A utilização do argumento de política externa, acompanhado de denúncias ressentidas ao "imperialismo americano", foi mais característico nos governos de Getúlio Vargas, Jânio Quadros e João Goulart. Mas Moscou também serviu ocasionalmente para o mesmo mister de cabide de sombra. Não devemos esquecer que o golpe de 1937 foi dado por Getúlio Vargas invocando sobretudo a ameaça comunista. O olho de Moscou! Schneider e Skidmore parecem ignorar que ocorreu também uma liderança carismática de "direita", com invocação do entusiasmo nacionalista (foi o caso do Integralismo e, até certo ponto, do Lacerdismo). Mas, de qualquer maneira, a aliança do populismo com o nacionalismo - "nacional-populismo" como ideologia nuclear da conjuntura - constituiu a grande idéia-força, dispondo da energia emocional necessária à propulsão de nossa agitada vida política no período 1930-1964.

Poderíamos salientar, a esta altura da discussão, que, dos três tipos de autoridade concebidos por Max Weber - a autoridade tradicional, a autoridade carismática e a autoridade racionallegal - o coronelismo corresponderia à primeira, o populismo à segunda, sendo que, de sua aliança, tiraram força dos líderes brasileiros de sucesso, como foi o caso de Getúlio Vargas. Os que se ergueram na base exclusiva do apelo carismático (ou demagógico se quiserem) brilharam com fulgor singular no firmamento da política brasileira, porém só transitoriamente. Foi necessária a Revolução de 64 para quebrar-lhes o fascínio duvidoso, impondo o terceiro tipo, racional-legal, de autoridade. É natural que, atados aos modelos liberais-constitucionalis-
tas americanos, seja o regime que ora nos governa, a principal preocupação desses críticos da Revolução brasileira. Com exceção de G. A. Fiechter (o que é paradoxal, pois se trata de um suíço), os outros revelam indiscutível má vontade para com 
o suposto "militarismo" de nosso sistema. Invariavelmente equacionam a presidência de militares com a ditadura, o que é evidentemente incorreto pois o único ditador que tivemos foi um civil, ao passo que as presidências militares têm, em geral, correspondido a um maior respeito à lei.

Samuel Huntington reconhece o papel positivo dos militares nos países do Terceiro Mundo em geral. Esquematiza a situação acentuando que o soldado é radical no sistema oligárquico; participante e árbitro no mundo da classe média; e conservador quando a sociedade de massa surge no horizonte. Isso quer dizer que as classes armadas seriam, basicamente, defensoras de uma política centrista, inimigas dos extremismos (tanto o reacionário quanto o subversivo), favoráveis aos métodos pacíficos e evolucionistas de reforma, e exprimindo, de um modo geral, os anseios da classe média esclarecida.

Lembro-me que, pela primeira vez, ouvi essa tese, brilhantemente defendida pelo Sr. Carlos Lacerda em 1955, em seminário na Universidade de Columbia, New York. Causou verdadeiro escândalo entre um grupo variado de ex-Presidentes, políticos, jornalistas e professores latino-americanos, todos eles exilados e foragidos de ditaduras que grassavam então no Peru, Argentina, Colômbia, Venezuela, República Dominicana, etc. Carlos Lacerda pregava, embora exilado voluntariamente após o golpe 11 de novembro de 1955, a imposição violenta da democracia através da tutela militar. Era a tese antiga de Rousseau: "é preciso obrigar o homem a ser livre"...

A opinião de Huntington coincide com o ponto de vista, hoje muito difundido no Brasil, de que as Forças Armadas representariam de fato o Poder Moderador da República.

Segundo outro scholar, José Nun, as Forças Armadas constituiriam o único elemento de organização e coesão da classe média, para defender seus interesses diante do perigo de choques catastróficos entre as velhas oligarquias latifundiárias e as massas em ascensão, garantindo as conquistas democráticas. Seriam, em suma, "a instituição melhor estruturada da classe
média".

Os estudos mais sérios nesse sentido são os de Alfred Stepan, que escreveu no início da Presidência Médici. Algumas de suas pesquisas são curiosíssimas. Com a meticulosidade que R. Serv. públ., Brasilia, 108 (3) set./dez. 1973 
caracteriza os pioneiros do Klondyke, Stepan se deu ao trabalho de analisar estatisticamente a procedência regional, nível social, curriculum vitae e outros dados que permitem colocar na devida perspectiva a classe dos oficiais brasileiros.

Um de seus achados mais divertidos se encontra no quadro em que, dividindo os generais brasileiros de 1964 em três grupos, a saber, a) o core group, ou grupo central de Castelistas que montaram o golpe de março e governaram na primeira Presidência revolucionária; b) os demais generais que logo aderiram à Revolução; e c) os marginais, que permaneceram fiéis ao Presidente Goulart - Stepan os classifica segundo quatro critérios. Eis o resultado: $60 \%$ dos Castelistas foram veteranos da FEB, contra só $25 \%$ dos Goulartianos; $90 \%$ fizeram estágio na ESG entre os Castelistas, $62 \%$ entre os revolucionários não-Castelistas e $50 \%$ entre os Goulartianos; $100 \%$ dos da ESG foram primeiros da classe em algum curso, contra $33 \%$ e $20 \%$, respectivamente, para os dois outros grupos; $100 \%$ do grupo central valeram-se de treino no exterior, contra $24 \%$ e $20 \%$ para os demais.

Stepan destrói também alguns mitos. Confirma a origem essencialmente democrática da oficialidade do Exército e, concomitantemente, prova que o corpo de oficiais não constitui uma "casta" no sentido estrito da palavra. De 1930 para cá, teria caído de 20 para $6 \%$ a proporção de oficiais originários das classes altas ou abastadas da população. Teria crescido, na mesma proporção, o recrutamento da AMAN nas classes mais modestas, inclusive de filhos de proletários e homens de cor. $60 \%$ da oficialidade não pertence a famílias militares, isto é, são filhos de pais que tinham profissões civis.

Stepan critica, entretanto, a crença vulgarizada de que o Exército seria fator saliente de integração nacional. Argumenta com o fato de que os grupos mais numerosos de oficiais são de origem carioca (o que quer dizer, filhos de oficiais que serviam na maior guarnição do país, a Vila Militar) e de origem gaúcha. O domínio dos gaúchos possui evidentemente motivações psicológicas históricas que quase não são avaliadas por Stepan. A proporção diminuta de oficiais paulistas é fato bastante conhecido, que dispensa comentários. O professor americano alega, contudo, haver uma tendência muito sensível dos oficiais gaúchos de servirem no Terceiro Exército, dos nordes- 
tinos no Quarto Exército e dos cariocas no Primeiro Exército. Assim, quando a opinião militar se cindiu perigosamente por ocasião do episódio da renúncia de Jânio Quadros, o Terceiro Exército teria tomado uma titude rebelde em última análise favorável à posse de Goulart - em virtude do fervor regional dos oficiais que o compunham. É dessa crise que deduz Stepan a sua tese, esquecido todavia que, entre os generais que, em 64, derrubaram João Goulart, havia dois gaúchos que já ocuparam a Presidência da República e um terceiro que a ocupará em breve.

G. A. Fiechter salienta, igualmente, o caráter democrático do recrutamento da oficialidade e sua natureza de expressão organizada e profissionalizada dos anelos da classe média brasileira. Insiste no fato, realmente da maior relevância, que o fenômeno saliente no desenvolvimento do Brasil nas últimas décadas tem sido o crescimento de uma vigorosa classe média, a qual não deseja se ver privada de suas conquistas pela agitação populista. Isso - que aliás salta aos olhos de todos, salvo daqueles que, por sectarismo cego, continuam martelando na tese da má distribuição dos benefícios do Desenvolvimento ("os ricos cada vez mais, os pobres etc.") - corresponde à emergência das Forças Armadas como fator político decisivo. Fiechter cita os estudos de L. C. Bresser Pereira sobre a origem não-oligárquica dos industriais de S. Paulo.

Fiechter também desmente as acusações de militarismo no Brasil, invocando nossos orçamentos militares que, entre 66 e 69 , consumiram apenas $2,2 \%$ do PIB, ao passo que, na Suiça, país neutro e pacifista, seriam de $2,4 \%$ e entre os membros da OTAN de $3,8 \%$ em média. Para não falar de nações como a Suécia e Israel que são as que, per capita, mais gastam no mundo com sua defesa. Em relação a seu território e população será o Brasil, provavelmente, o país que mantém o menor contingente de homens armados no mundo. Vale notar que o Prof. Bradforá Burns, o qual se faz passar por especialista em assuntos brasileiros, nos acusa de mais despender com a Defesa do que com a Educação, mas esquece, ao comparar as respectivas dotações federais, que o grosso das despesas de ensino do $10^{\circ}$ e $2 .^{\circ}$ graus, e parte do Universitário, se coloca nos orçamentos estaduais e municipais. Só o de S. Paulo é maior do que o do MEC.

Tece ainda Fiechter uma série de comentários interessantes sobre o que chama de processo de "profissionalização" dos militares brasileiros. Possui esse aumento da capacidade técnica, 
evidentemente, muitas vantagens, não apenas em termos de maior eficiência de nossas FF.AA. para as missões específicas de sua alçada, mas ainda para o papel que desempenham na administração pública. Nota, porém, que o mesmo fenômeno pode também trazer perigos, caso a profissionalização militar não seja acompanhada de um desenvolvimento paralelo nos quadros políticos e administrativos civís. Pois se converteria num "militarismo estrutural", como conseqüência da crescente disparidade de preparo e eficácia entre os dois setores da elite dirigente.

Fiechter, Schneider e Stepan salientam todos a importância de primeiro plano da Escola Superior de Guerra no quadro da Revolução brasileira. Schneider vai a ponto de asseverar que "raramente, ou talvez nunca, uma instituição educacional teve, em menos de duas décadas de existência, um impacto tão profundo no correr do desenvolvimento de uma nação". Infelizmente, esse autor prejudica sua análise com informações errôneas e algumas vezes fantásticas.

Isso, aliás, é uma crítica que se pode dirigir a muitos desses professores universitários que, a par de seu método meticuloso de investigações, extremamente apurado, deixam às vezes escapar surpreendentes falhas de informação. Quero oferecer alguns exemplos clamorosos no erudito livro de Schneider que termina com uma lista de suas fontes, de 25 páginas! Refere-se a "seis anos de governo militar" por ocasião da Proclamação da República (pg. 41). Anuncia a "dissolução do Congresso" em 1968 (pg. 204) embora, mais adiante, escreva corretamento que se tratou de um "recesso". Fala muito na vida de D. Helder Câmara, mas esquece de informar que esse prelado, entre outras coisas, foi na época integralista (pg. 255). Afirma que os estagiários civis da ESG recebem patentes de coronel para cima (pg. 250) (o que me entristece, pois eu não recebi...) informa ainda que "o MUDES desapareceu", que "o Professor Almir de Castro foi purgado da UnB", que o deputado Murilo Badaró foi cassado e que 43 diplomatas foram demitidos pelo Al-5 (na realidade só 14 ). Algumas interpretações são evidentemente exageradas ou simplesmente tendenciosas. Dizer que "houve suspensão do processo" eleitoral (pg. 21) e "ausência de eleições competitivas" (pg. 344) seria, a rigor, correto ao nivel do executivo federal, mas é falso no nível dos executivos estaduais e do legislativo federal. As "repetidas derrotas nas urnas" do Governo (pg. 152) representariam uma noção de natureza onírica que muito deveria ale- 
grar a oposição . A descrição do seqüestro do Embaixador Elbrick como um protesto de "elementos democráticos" (sic) e do terrorismo em geral como uma "escapatória de intelectuais e jornalistas sem outros canais normais de expressão" (pgs. 218/285) viola lamentavelmente o princípio da verdade. E quanto à "derrubada do Governo Costa e Silva por um golpe interno" (pg. 281) me parece fantasmagórico.

Muitos desses autores, inclusive Skidmore e Schneider, revelam sem querer um desconhecimento básico da realidade brasileira ao usarem estranhos patronímicos para nossos políticos em evidência. Falam assim do governador "De Barros", do Presidente "Branco" e do "Presidente Garrastazú" (neste último caso em evidente confusão com a prática espanhola de usar o nome do pai como penúltimo patronímico).

A obsessão com o militarismo os leva, também, a exageros. Assim, Schneider descreve o Ministério Costa e Silva como composto quase exclusivamente de militares, citando entres estes Costa Cavalcanti, Passarinho e Macedo Soares. Com essa teoria, os Estados Unidos também viveriam sob regime militar, pois todos seus Presidentes e quase todos os Ministros, desde Truman, foram ou são oficiais da reserva do Exército (Truman e Johnson) ou da Marinha (Kennedy e Nixon), pois serviram como tal na Primeira ou na Segunda Guerras Mundiais.

Esses pequenos deslizes não seriam graves, revelando apenas uma falta de cuidado na revisão dos livros. Mais importantes são as previsões e conclusões, porque afetam a própria substância das teses defendidas. Schneider, por exemplo, afirma do alto de sua onisciência délfica que as perspectivas do Presidente Médici terminar o mandato não são melhores do que as dos seus antecessores, isto é, $50 \%$. Não atino de como ele chegou a esse cálculo percentual. Esse distinto e letrado catedrático também afirma várias vezes que "a estagnação econômica" (sic) e as "repetidas derrotas nas urnas" comprometem seriamente 0 atual regime brasileiro. Cita em apoio de tão audaciosa fantasia a observação de Huntington de que o declínio da ordem política em toda a Ásia, Africa e América Latina, no período de pós-guerra, acarretou a subversão da autoridade, da eficiência e da legitimidade. A qualquer pessoa de bom senso parecerá que nossa situação é precisamente o inverso dessa visão pessimista. 
Com dificuldade para concordar ou para repelir a categoria de "Revolução" que é dada ao processo de transformação iniciado em 1964, Schneider também não aceita o termo de Contra-Revolução. Para ele seria um "processo" de "golpes dentro do golpe". Acusa então o regime de ser uma "ditadura nua e crua", apoiando, ao que parece, o ponto de vista de Bradford Burns e de outros "liberais" da Esquerda Festiva americana (pink chic). Esses homens evidentemente não visitaram o planeta Marte, nem mesmo Hanói e Saigon, nem qualquer das inúmeras capitais apoiadas respectivamente pela União Soviética e por seu próprio país, para tão destrambelhada informação propagandística.

Schneider simpatiza, em conclusão, com parecer de nosso douto Hélio Jaguaribe que classifica o regime brasileiro como "fascismo colonial" e apóia as inspiradas profecias desse ilustre intelectual (que, juntamente com Celso Furtado, granjeou respeitável auditório nas Universidades americanas varridas pelo vendaval dionisíaco). Hélio Jaguaribe, como se sabe, prevê o crescimento da opressão a fim de compensar a "estagnação econômica" que descobre em nossa terra. Schneider também prevê a desunião nas Forças Armadas e novas revoluções de jovens militares que derrubarão o Presidente Médici...

Skidmore, sem dúvida mais erudito e mais sólido do que Schneider, acredita que o Brasil esteja registando uma verdadeira "tomada de consciência", conforme fora pregado pelos ideólogos nacionalistas e desenvolvimentistas da década dos 50 . Admite que "os limites da improvisação se estavam tornando óbvios desde o fim da Presidência de Juscelino Kubitschek". Ao procurar compreender a solução autoritária ao cul-de-sac político brasileiro, Skidmore se pergunta em que momento "a suspensão do sistema democrático" se tornou inevitável. Para ele, o dilema brasileiro seria o seguinte: Desenvolvimento com Estabilidade $\mathrm{X}$ Democracia.

O próprio Schneider reconhece que a burocracia brasileira, vasta e mal coordenada, corrupta e politicamente influenciável, distribuída por mais de 150 agências autônomas, não pode atender às exigências do progresso, gerando assim, como corretivo, a partir de 1966, a aliança dos militares com os tecnocratas. A tecnocracia castelista é então acusada de ignorar as realidades em sua concentração exclusiva sobre "políticas corretas", decisões "racionais" e "boa imagem no exterior". Custo, porém, a 
entender como possam "políticas corretas", "decisões racionais" e "boa imagem no exterior" serem criticadas como tal. Seria porventura mais democrático que tomasse o governo decisões irracionais, seguindo políticas incorretas que gerassem uma péssima imagem no exterior?

Robert Daland, citado por Schneider e escrevendo no princípio da administração Costa e Silva, pergunta se a burocracia brasileira será capaz de planejar, organizar e executar o Desenvolvimento econômico que, há mais de duas décadas, constitui o objetivo precípuo de todos os governos. David Apter, igualmente citado, classifica o do Brasil atual como híbrido entre o "sistema reconciliador modernizante" e o "sistema reconciliador industrializador". Seria também "burocrático-militar".

Fiechter é muito mais incisivo, muito mais preocupado também e, obviamente, mais versado em economia do que seus colegas americanos, quando explica o sucesso do atual regime no terreno do Desenvolvimento ao acentuar que "a Planificação se tornou o Programa da. Revolução". O fenômeno poderia esclarecer-se pelo fato de que os militares empolgaram o poder, não a título pessoal, mas na crença de que constituem um "corpo organizado" racionalmente, o único existente em nossa terra. Sendo assim, estariam relativamente próximos do ideal weberiano!

No Brasil, nenhum militar se sobrepôs à disciplina hierárquica imposta pela corporação. Os que o tentaram foram sumariamente eliminados. Quem comanda não é um general, nem mesmo "os generais", mas uma instituição: o Alto Comando das Forças Armadas. É nessa instituição que está realmente investido o poder. Veja-se o próprio estilo do golpe de 31 de março: encabeçado originariamente pelo comandante de uma guarnição relativamente secundária, com apoio dos quatro prin. cipais governadores de Estado, a Revolução guindou sucessivamente ao poder supremo militares que foram indicados na base de seus méritos, e não como resultados das peripécias da conspiração antigoulartiana, nem em virtude de qualquer auréola carismática surgida eventualmente ao fragor dos choques politicos. É essa subordinação das personalidades a decisões coletivas - subordinação tão contrastante com nossa idiossincrasia personalista - que explica o poder revolucionário das Forças Armadas - as quais certamente continuarão a sustentá-lo enquanto se mantiverem unidas. É também essa circunstância que torna nosso regime original, no quadro do chamado "Terceiro 
Mundo", dando autenticidade à nossa árdua caminhada em busca do "modelo político" brasileiro.

Vemos assim, em conclusão, que os melhores entre os autores estrangeiros que se hão debruçado sobre nossas atuais circunstâncias, procuram definir o "modelo" como determinado pela idéia do Plano. Alfred Stepan e G.A. Fiechter chegam a considerar o Plano como o agente principal do regime "modernizante" sui generis sob o qual vivemos. Fiechter relaciona mesmo o papel dos militares em nosso governo ao fato de constituírem a única corporação capaz de dar estabilidade e continuidade ao cumprimento do planejamento econômico a longo prazo, conforme exigência das tensões resultantes da revolução industrial, sem porém deixarem de "facilitar o acesso ao poder de novas camadas sociais".

Com efeito, não só são as Forças Armadas as únicas capazes de impor a concepção do Plano estratégico, mas de executálo numa contınuidade suficiente para que frutifique, permitindo a renovação dinâmica das elites dirigentes e burocráticas. Contrariamente à crença geral, não foram só os economistas que introduziram a idéia do planejamento no Brasil. Se essa idéia (por que não dizê-lo? de origem russa) veio a tornar-se uma das facetas mais originais de nosso pseudo-capitalismo, com seu modelo econômico singular (onde a intervenção do Estado é muito mais vasta e profunda do que em países ditos "socialistas" como a Suécia, por exemplo), devemo-lo mais aos militares do que aos economistas. (Talvez o devamos, em primeira mão, aos arquitetos e urbanistas, os quais, em Brasília, conceberam simbolicamente o futuro através do conceito do Plano-Piloto!).

Os militares, quando verdadeiros profissionais, pensam em termos e com a disciplina do planejamento estratégico, a técnica do qual constitui, incidentalmente, a parte final e conclusiva no treino oferecido pela ESG a civis e militares de alta patente no Curso Superior de Guerra.

Está implícito nos votos dos autores acima mencionados que são simpáticos à causa de nossa Revolução - e em nossos próprios votos, naturalmente! - que esse Planejamento venha eventualmente a incluir também a estrutura de nossas futuras instituições políticas, dentro do binômio Segurança e Desenvolvimento. 


\section{BIBLIOGRAFIA}

- Blakanoff, Eric W., ed. - The Shaping of Modern Brazil - Baton Rouge,
1969.

- Bloem, Ruy - A Crise da Democracia e a Reforma Eleitoral - São Paulo, 1955.

- Burns, E. Bradford - Nationalism in Brazil, A Historical Survey -

- Combret, François de - Les 3 Brésil - Paris, 1971.

- Dulles, John W. F. - Unrest in Brazil - Political-Military Crises, 19551964. - U. of Texas, 1970.

- Dubnic, Vladimir Reisky de - Political Trends in Brazil - Washington,

- Emmerson, Donald - Students and Politics in Developing Nations N. York, 1968.

- Fiechter, George-André - Le Régime Modernisateur du Brésil - Ge-
nebra, 1972. - Huntington, Samuel P. ed. - Changing Patterns of Military Politics -
N. York, 1962 .

- Huntington, Samuel P. ed. - Political Order in Changing Societies Harvard U. Press, 1968. - Jaguaribe de Matos, Hélio - Brazilian Nationalism and the Dynamics of
its political development.

- Jaguaribe de Matos, Hélio - Desenvolvimento econômico e desenvolvimento político - R. J. Fundo de Cultura, 1962. - Meira Mattos, Gen. - Ensaios sobre a doutrina política da Revolução

- Meira Penna, J. O. de - Política Externa, Segurança e Desenvolvi-

- Morazê, Charles - Les Trois Âges du Brésil - Paris.

- Nun, José - A Latin-American Phenomenon: the Middle-class Military Coup in The Politics of Conformity in Latin-America - Londres, 1967.

- Pereira, L. C. Bresser - Desenvolvimento e Crise no Brasil - R. J.,

- Petras, James, ed. - Latin-America: Reform or Revolution - N. York,

- Schneider, Ronald - The Political System of Brazil.

- Skidmore, Thomas - Politics in Brazil - an experiment in Democracy - N.Y., 1967.

- Stepan, Alfred - The Military in Politics Changing patterns in Brazil -
Princeton, 1971. 